\title{
"We Listened to it Because of the Message": Juvenile RUF Combatants and the Role of Music in the Sierra Leone Civil War
}

\author{
CORNELIA NUXOLL
}

\section{Introduction}

This article will explore the role of music in the Sierra Leonean conflict and the extent to which music facilitated the construction of identities and the formation of social cohesion within the Revolutionary United Front (henceforth RUF) rebel movement. ${ }^{1}$ Moreover, it will look at the RUF's use of music as an instrument of terror in this war. First, I will briefly outline the dynamics that gave rise to the war, and then I will look into reasons for the widespread juvenile participation, touching on diverse motives and the heterogeneous composition of members within the RUF revolution. With regard to the juvenile combatants in this conflict, I will focus on how they utilized music in different ways, for different reasons and various ends.

\section{Background}

From 1991 until 2002 a civil war raged in the West African country of Sierra Leone. After decades of increasing state decline due to the personal rule of one-party politics, bad governance, nepotism, political corruption, and economic failure, the RUF invaded Sierra Leone, claiming to overthrow the then ruling All People's Congress (APC) government with support from Charles Taylor's Liberian special forces, rebel combatants of the National Patriotic Front of Liberia (NPFL).

The mismanagement of the APC government had left Sierra Leoneans in a state of abject poverty with no proper access to democratic participation in decision-making processes or to political representation. The failures in governance and the deterioration of institutional processes led to the weakening of the state's capacity to ensure the security and livelihood of its citizens, thus creating the conditions for a collapsing state. These factors contributed to the growth of poverty and created a sense of marginalization. The grievances that resulted from these conditions fuelled and sustained the coming conflict of the $1990 \mathrm{~s}^{2}$

\footnotetext{
${ }^{1}$ The term "rebel" is not used in order to evaluate, judge, or categorize the nature of the insurgency group but derives from interviews conducted with former RUF combatants who employ the term, among others, to describe either the RUF movement or their own role within the conflict.

${ }^{2}$ For the most detailed analyses of the Sierra Leonean war, its account and its root causes see Paul Richards, Fighting for the Rainforest: War, Youth and Resources in Sierra Leone (Oxford: James Currey for the International African Institute, 1996); “The Social Life of War: Rambo, Diamonds and Young Soldiers in Sierra Leone,” Track Two 8, no. 1 (1999), http://ccrweb.ccr.uct.ac.za/archive/two/8_1/p16_social_life_of_war.html; "Emotions at War: A Musicological Approach to Understanding Atrocity in Sierra Leone," in Public Emotions, ed. Perri 6, et al., 62-84 (Basingstoke: Palgrave, 2007); “Against 


\section{RUF Violence and Juvenile Combatants}

The RUF launched its insurgency into Sierra Leone from neighboring Liberia, entering Kailahun District in the east in March 1991. ${ }^{3}$ The rebellion's first control regions were core areas of political opposition and dissent. Thus, civilians living in these areas were initially sympathetic to the idea of liberation from a "rotten system" and supportive of the endeavors of the RUF insurrection. However, the RUF quickly revealed itself to be an abusive movement, which sustained itself through looting, predatory resource extraction, and forced recruitment. The atrocities inflicted on innocent people soon resulted in a complete loss of support from the civilian population. ${ }^{4}$

In fact, the Sierra Leone civil war is widely associated with "blood diamonds" and is infamous for its human rights violations; its hallmark atrocities of limb amputations; and the widespread forced, coerced, and voluntary involvement of juvenile and child combatants. ${ }^{5}$

Within scholarly discussions, the conflict is sometimes labeled a "senseless war" ${ }^{\text {" }}$ or simplified as a

Ethnicity - Some Anthropological Arguments" (paper presented at "Rethinking Ethnicity and Ethnic Strife: Multidisciplinary Perspectives," conference at Central European University, Budapest September 25-27, 2008); Paul Richards, ed., No Peace, No War: An Anthropology of Contemporary Armed Conflicts (Oxford: James Currey, 2005); Krijn Peters and Paul Richards, "Youths in Sierra Leone: 'Why We Fight," Africa: Fournal of the International African Institute 68, no. 2 (1998): 183-210; Danny Hoffman, The War Machines: Young Men and Violence in Sierra Leone and Liberia, Cultures and Practice of Violence (Durham, NC: Duke University Press, 2011); Krijn Peters, War and Crisis of Youth in Sierra Leone, International African Library (Cambridge: Cambridge University Press, 2011); David Keen, Conflict and Collusion in Sierra Leone (Oxford: James Currey, 2005); Lansana Gberie, A Dirty War in West Africa: The R.U.F. and the Destruction of Sierra Leone (London: C. Hurst \& Co. Ltd., 2005); Myriam Denov, Child Soldiers: Sierra Leone's Revolutionary United Front (Cambridge: Cambridge University Press, 2010); Abdullah Ibrahim, ed., Between Democracy and Terror: The Sierra Leone Civil War (Dakar: CODESRIA, 2004); Truth and Reconciliation Commission, Witness to Truth: Report of the Sierra Leone Truth E Reconciliation Commission, vol. 3A, 2004, http://sierraleonetrc.org/index.php/view-the-final-report/table-of-contents.

${ }^{3}$ Other endemic warring factions involved in this war were the Sierra Leonean Army (SLA), the grassroots militia forces eventually subsumed as the Civil Defence Forces (CDF) established and spearheaded mostly by Mende-speaking Kamajors, later the Armed Forces Revolutionary Council (AFRC) junta, joined forces consisting of SLA splinter groups and RUF combatants and the West Side Boys, an army splinter group.

${ }^{4}$ Most of the former RUF combatants claimed that the NPFL forces were the ones who introduced the atrocious conduct towards civilians. After the expulsion of the Liberian forces, however, atrocities committed against the civilian population continued. While some former rebels argued that opportunistic fighters adopted NPFL conduct, others explained the ongoing violence and destruction as a byproduct of the war more generally, as an expression of their disgruntlement towards the fact that civilians had withdrawn their support for the movement and due to the fact that they needed to sustain themselves.

${ }^{5}$ There are a myriad of scholarly works and humanitarian reports on the issue of underage soldiering in Africa, dealing with recruitment strategies, the transformation of minors into soldiers, young people's motives for enlisting, forced recruitment and trauma; analyzing the conditions, underlying causes and implications of the young being affiliated with armed forces as well as their demobilization and reintegration into civilian life in Sierra Leone and other contemporaneous wars. For an extensive list of available literature on youth and conflict more generally, see Ilene Cohn and Guy S. Goodwin-Gill, eds., Child Soldiers: The Role of Children in Armed Conflicts (Oxford University Press, 1994); Rachel Brett and Irma Specht, Young Soldiers: Why They Choose to Fight (Boulder: Lynne Rienner Publications, 2004); Graça Machel, "Impact of Armed Conflict on Children" (United Nations document A/56/306, August 26, 1996), http:/www.unicef.org/graca/; Kendra E. Dupuy and Krijn Peters, War And Children: A Reference Handbook (Santa Barbara: ABC Clio, 2010); P. W. Singer, Children at War (Berkeley: University of California Press, 2006); David M. Rosen, Armies of the Young: Child Soldiers in War and Terrorism (New Brunswick, NJ: Rutgers University Press, 2005); Denov, Child Solders; Michael Wessells, "Recruitment of Child Soldiers in Sub-Saharan Africa: An Ecological Analysis," in The Comparative Study of Conscription in the Armed Forces, ed., Lars Mjoset and Stephen van Holde, 237-254, Comparative Social Research 20 (Emerald Group, 2002); and Marc Sommers, Youth and Conflict: A Brief Review of Available Literature (USAID, Education Development Center, EQUIP3/Youth Trust, 2006). See also online resources provided by human rights organizations and advocacy groups such as War Child International, Child Soldiers International, the Coalition to Stop the Use of Child Soldiers, Save the Children and materials provided by Human Rights Watch and Amnesty International.

${ }^{6}$ See for example Abdullah, Between Democracy and Terror, 2004; and Nathaniel King, Conflict as Integration: Youth Aspiration to Personhood in the Teleology of Sierra Leone's 'Senseless War' (Uppsala: Nordiska Afrikainstitutet, 2007). 
conflict only driven by greed for diamonds. ${ }^{7}$ The Sierra Leonean scholar Ibrahim Abdullah largely denies that the RUF had any political agenda and describes its combatants as members of the "lumpenproletariat," uneducated, unemployed youths and thugs. ${ }^{8}$ Robert Kaplan, for example, offers the theory of an emerging "New Barbarism" to explain the Sierra Leonean conflict case.

Although it was the RUF's common practice to forcefully recruit underage fighters to sustain their insurgency, suggesting that the rebel group largely consisted of forced conscripts and that it only held a small percentage of volunteer combatants, there is evidence that during the early stages of the war, the movement did indeed gain a considerable number of volunteer followers. Bad governance had created a generation of disgruntled and disadvantaged youths who were easily attracted to the revolutionary cause of the RUF. The high numbers of minors involved in this conflict may therefore mirror the fact that their enlistment presented the best amongst available options. Social anthropologists Paul Richards, Krijn Peters, and others have argued that African child combatants may possess political consciousness and awareness and that their enlistment, even when coerced, sometimes reflects a strategy, operating within the constraints imposed by the course of war, that ensures their own survival and that of their families. ${ }^{10}$ Joining irregular forces may present a good opportunity to escape from the political, social, and economic marginalization young people often face, given the political corruption, wrecked educational system, and economic failure of many weak or failing African states. Apart from ideological aspirations to actually bring about political and economic changes, being part of a militia may serve to provide some kind of training, education, and employment for young people who are otherwise faced with poor prospects for earning a livelihood. Richards convincingly argues that a determined "agency of youth" plays a critical role in understanding the dynamics of war and violence in the Sierra Leone conflict. ${ }^{11}$ Their conscription may reflect a means of winning back some sort of self-determination by acting out what they perceive as 'selfdefense'.

In light of the flagrant human rights violations committed, RUF rebels were mostly discarded as brutish delinquents. However, it is wise to challenge this assumption and examine to what extent there was any political agenda or ideological motive in play. Despite the fact that the RUF seems not to have been a convincingly coherent political movement, David Keen (2002) argues that the extreme violence in this conflict does not necessarily prove the lack of any political beliefs or felt injustices but rather suggests that these were poorly expressed and executed in a highly distorted form. Even if, over time, self-

\footnotetext{
${ }^{7}$ For a debate on "greed or grievance" as driving forces in civil wars, see Paul Collier and Anke Hoeffler, "Greed and Grievance in Civil War,” World Bank Policy Research Working Paper 2355 (World Bank, 2000), http://dx.doi.org/10.1596/1813-9450-2355.

${ }^{8}$ Abdullah, "Bush Path to Destruction: The Origin and Character of the Revolutionary United Front/Sierra Leone," Fournal of Modern African Studies 36, no. 2 (1998): 203-235; Abdullah and Patrick Muana, The Revolutionary United Front of Sierra Leone: A Revolt of the Lumpenproletariat, in African Guerillas, ed. Christopher Clapham, 172-193 (Oxford: James Currey, 1998).

${ }^{9}$ Robert D. Kaplan, The Ends of the Earth: A fourney at the Dawn of the 21st Century (New York: Random House, 1996); Paul Richards coined the term "New Barbarism" criticizing Kaplan's depiction of backwardness and depravity as something peculiar to the African continent. Richards, Fighting for the Rainforest.

${ }^{10}$ See for example Richards, Fighting for the Rainforest; Peters and Richards, "Youths in Sierra Leone"; and Peters, Richards, and Koen Vlassenroot, "What Happens to Youth During and After Wars?: A Preliminary Review of Literature on Africa and an Assessment of the Debate" (RAWOO working paper, October 2013), http://dspace.library.uu.nl/handle/1874/2898.

${ }^{11}$ Richards, Fighting for the Rainforest. There are a number of scholarly works on the "anthropology of youth" in contemporary African societies and elsewhere, dealing with young people's widespread sociopolitical and economic marginalization and their maneuvering between positions of ageny and victimhood, employing constructive as well as destructive means in order to negotiate, claim and improve their societal status. See for example Alcinda Honwana and Filip Boeck, eds., Makers and Breakers: Children and Youth in Postcolonial Africa (Oxford: James Currey, 2005); Ineke van Kessel and Jon Abbink, eds., Vanguard or Vandals: Youth, Politics and Conflict in Africa (Leiden: Brill Academic, 2004).
} 
enrichment, became the principal driving force of the RUF rebellion, then it is still pivotal to understand what generated this greed and the readiness to use violence in the first place. Keen acknowledges that on the one hand a weak political ideology was more likely to promote selfish behavior, violence, and abuse than prevent it, but on the other hand, by humiliating civilians and committing atrocities, the rebels seemed to be driven by the need for recognition and respect, however forcibly demanded from the civilians they felt had turned against them. In this regard, war enabled the establishment of its own "rational violence framework," linking violence to psychological, political, and economic motives. ${ }^{12}$

The political objectives of the RUF defy easy categorization. On the whole, the RUF movement seems to have assembled or at least over time created a very heterogeneous group of combatants with very different agendas: founding ideologues and educated moderates were set alongside seemingly apolitical Liberian NPFL vanguards and mercenaries, and a growing number of voluntary, coerced, but mostly forced recruits. Some of the RUF members joined out of political conviction, and some recruits may have been successfully indoctrinated with a measure of political ideology. Some joined out of self-preservation, while others learned about and stayed in the movement because of the incentives of power and selfenrichment. Most of them were recruited by force. It seems, however, that early recruits were more likely to have joined the movement voluntarily and out of political conviction. Later recruits were most likely to be forced into conscription and were no longer politically instructed on what the revolution was about. Among these later recruits were also an increasing number of combatants who acted according to selfserving motives.

In order to better understand what makes young people decide to join armed forces and where they take their inspiration from to rise against authorities, it is worth exploring where young people look for, find, and create role models, ideas, ideals, and identities. In most societies, young people are at the forefront of relating to, consuming, and producing elements of popular culture. For this reason, it is beneficial to look into products originating from popular culture, and particularly music, examining the ways in which young people use music as a communicative tool to position themselves as social and political agents. ${ }^{13}$

\footnotetext{
${ }^{12}$ Richards suggests that the RUF movement may have used terror as a statement and a means of "spectacle" in order to be widely recognized as a serious insurgency movement. Lansana Gberie contradicts this argument by pointing out that the majority of atrocities committed occurred far away from media coverage. He interprets the RUF's violent pathology as proof of the rebels' belief in impunity. Richards, Fighting for the Rainforest; Gberie, A Dirty War in West Africa.

${ }^{13}$ Richards has already discussed how popular media such as (anti-)war movies like First Blood starring Sylvester Stallone as Rambo were a motivating and instructive source of inspiration for juvenile combatants during the Sierra Leone conflict. Richards, Fighting for the Rainforest; and "The Social Life of War." For a discussion of the notion of a "morally neutral hero" in action films with reference to former youth combatants in Liberia, see Mats Utas, "Sweet Battlefields: Youth and the Liberian Civil War" (PhD diss., Uppsala University, 2003), http://www.divaportal.org/smash/get/diva2:163000/FULLTEXT01.pdf; and "Abject Heroes: Marginalised Youth, Modernity and the Violent Pathways of the Liberian Civil War," in Years of Conflict: Adolescence, Political Violence and Displacement, ed. Jason Hart, 111138 (New York: Berghahn Books, 2008). Some scholarly work has been done on the role and imagery of gangsta rap among RUF combatants and the army splinter group West Side Boys. Special focus lies on the iconography of the rap artist Tupac Shakur (2Pac) who was admired by combatants as an iconic (anti-)hero and imitated for his fierce masculinity and his status as social outcast and defiant underdog. See, for example, Marc Sommers, "Peace Education and Refugee Youth," in Learning for a Future: Refugee Education in Developing Countries, ed. Jeff Crisp, Christopher Talbot, and Diane B. Cipollone, 163-216 (United Nations High Commissioner for Refugees, 2001), http://www.unhcr.org/3b8albd84.pdf; Mats Utas and Magnus Jörgel, “The West Side Boys: Military Navigation in the Sierra Leone Civil War,” Fournal of Modern African Studies 46, no. 3 (2008): 487-511, http://magnusjorgel.se/home_m/WSB\%20Jmas.pdf; and Jeremy Prestholdt, "The Afterlives of 2Pac: Imagery and Alienation in Sierra Leone and Beyond," Fournal of African Cultural Studies 21, no. 2 (2008): 197-218. My own research suggests that rap music only gained momentum with RUF combatants when more urban youth joined their cadres in the mid-1990s, introducing earlier combatants from the provinces to rap music.
} 


\section{Music and Agency}

There is general accord that engagement with music can arouse emotional and cognitive responses that shape and alter the experiences of individuals every day. Music may act as a "change agent," allowing for different approaches towards and interpretations of constructions of the self and one's personal situation. ${ }^{14}$ Music is widely used to influence mood, whereby it intensifies or releases existing emotions; it relaxes people, helps them to focus or serves to distract them; it comforts, energizes, motivates, and inspires. Music provides resources to connect and reconnect with oneself and one's emotions. However, it is not music alone or any intrinsic property it contains that acts as a causal stimulus, creating or changing emotion in a person. Rather, music's affect is attributable; its power cannot be abstracted from its context of use. Music is, rather, a device that people utilize in order to gain access to emotional experiences and responses as they are looking for and dealing with issues that are already dormant but not yet fully grasped or negotiated. ${ }^{15}$ The structuring properties of music allow it to form a major constitutive means of human agency and provide a resource through which personal and social lives can be configured. Music may foster critical consciousness and is a referent for action and an ordering device, organizing people in real time. ${ }^{16}$

People turn to popular commodities or texts in order to activate their potential meanings, thus engaging in "culture making." 17 The relationship between music and identity formation, the realization of cultural subjectivity through music has long been acknowledged. As Turino and others have pointed out, young people encountering a particular struggle in their personal and social identities look for musical styles that they can identify with, that will represent them, and that will align them with specific social groups. $^{18}$

In recent years, a growing pool of academic publications has helped to acknowledge that the very same powers music has for creating positive social relationships can also be used for suppressive, humiliating, and harmful ends. Music in armed conflicts finds use in both escalating conflicts and in the promotion of conflict resolution. ${ }^{19}$ Conversely, music's potential to incite, generate, and accompany violence and torture has been examined by Cloonan and Johnson, Cusick, Hirsch, Grant, and Fast and Pegley, among others. ${ }^{20}$

\footnotetext{
${ }^{14}$ John Sloboda, "Empirical Studies of Emotional Response to Music," in Cognitive Bases of Musical Communication, ed. Mari Riess Jones and Susan Holleran, 33-46 (Washington, DC: American Psychological Association, 1992); and Exploring the Musical Mind: Cognition, Emotion, Ability, Function (Oxford: Oxford University Press, 2004).

${ }^{15}$ Sloboda, Exploring the Musical Mind; and "Music Structure and Emotional Response: Some Empirical Findings," Psychology of Music 19, no. 2 (1991): 110-120; Tia DeNora, Music in Everyday Life (Cambridge: Cambridge University Press, 2000); Simon Frith, "Music and Identity," in Questions of Cultural Identity, ed. Stuart Hall and Paul du Gay, 108-127 (London: Sage Publications, 1996); and Frith, Performing Rites: Evaluating Popular Music (Oxford: Oxford University Press, 1996).

${ }^{16}$ DeNora, Music in Everyday Life; Music-In-Action: Selected Essays in Sonic Ecology (Aldershot: Ashgate, 2011); and After Adorno: Rethinking Music Sociology (Cambridge: Cambridge University Press, 2003).

${ }^{17}$ John Fiske, Reading the Popular (London: Routledge, 1989).

${ }^{18}$ Thomas Turino, Music as a Social Life: The Politics of Participation (University of Chicago Press, 2008), 93-94.

${ }^{19}$ See, for example, John Morgan O'Connell and Salwa El-Shawan Castelo-Branco, Music and Conflict (Chicago: University of Illinois Press, 2010); and Olivier Urbain, ed., Music and Conflict Transformation: Harmonies and Dissonances in Geopolitics, Toda Institute Book Series on Global Peace and Policy (London: I.B. Tauris, 2008).

${ }^{20}$ Bruce Johnson and Martin Cloonan, "Killing Me Softly with His Song: An Initial Investigation into the Use of Popular Music as a Tool of Oppression," Popular Music 21, no. 1 (2002): 27-39; Johnson and Cloonan, Dark Side of the Tune: Popular Music and Violence (Aldershot: Ashgate, 2008); Suzanne Cusick, "Music as Torture/Music as Weapon," Transcultural Music Review 10 (2006), http://www.sibetrans.com/trans/a152/music-as-torture-music-as-weapon; Cusick, "You Are in a Place That Is out of the World . . ': Music in the Detention Camps of the 'Global War on Terror," Fournal of the Society for American Music 2, no. 1 (2008): 1-26; Lily E. Hirsch, "Weaponizing Classical Music: Crime Prevention and Symbolic Power in the Age of Repetition," Fournal of Popular Music Studies 19, no. 4 (2007): 342-358; Hirsch, "Do You Really Want to Hurt
} 


\section{Music and Political Consciousness amongst Juvenile Combatants}

In winter 2010-2011 and again in winter 2011-2012, I conducted fieldwork in Sierra Leone and primarily interviewed former RUF combatants. Most of them joined the movement early on and stayed with it until its final days in 2002. My sample suggests that early recruits were more likely to join the movement out of political conviction and perceived grievances than later recruits, who were predominantly forcefully and more arbitrarily recruited, and those who joined for the lure of power and material benefits. ${ }^{21}$ Even those interviewees who claimed to have been forcefully recruited and (apparently) successfully indoctrinated did not, in hindsight, dissociate themselves from the fact that they were members of the RUF. In the beginning of their military involvement in the early 1990s, most of these men were in their mid or late teens. ${ }^{22}$

If the involvement of many juvenile soldiers in the Sierra Leonean conflict reflects a means of protest against a "rotten system," then it is worth investigating to what extent music may have been a factor in shaping a political and revolutionary consciousness prior to and throughout the conflict. Furthermore, it is worthwhile to explore the significance of music as a source of motivation and inspiration for young people to either join irregular forces or continue to stay in them. It may also provide a means of assessing the existence and actual relevance of political ideology within the RUF movement.

Given that youthful combatants played a prominent role in the Sierra Leonean conflict and recognizing that youth are at the center of popular media and culture which in turn play an important role in matters of coming of age and as a means of identity formation, my current research explores the role, influence and impact of music on young combatants during the Sierra Leonean war. I look at how music inspired and motivated young fighters and how they related to and interpreted specific songs according to their needs and their situation. ${ }^{23}$ The musical genres that played a role in the lives of RUF fighters range from the work of international artists to local Sierra Leonean musicians and music from other African artists as well as commando songs composed within the rebel faction itself. In the following sections, I discuss two examples selected from my research findings to demonstrate the diverse appropriation of music (namely roots reggae and Sierra Leonean Bubu music) in forging and legitimizing rebel identity as well as the rebels' deliberate use of music to intimidate and terrorize. I will thereby demonstrate how music was used to deal with and shape the experiences of war. The article closes with a brief outlook on music in post-war Sierra Leone.

\section{Rebel Life and Reggae Music}

During the Sierra Leonean war, almost all of the RUF combatants I interviewed preferred to listen

\footnotetext{
Me? Music as Punishment in the United States Legal System," Popular Music and Society 34, no. 1 (2011), 35-53; M. J. Grant, "Musik im Dienst des Massenmords," in Musik und Gewalt (Berichte aus dem Nationalkomitee Deutschland im International Council for Traditional Music XIX), ed. Marianne Bröcker, 259-268 (Münster: Verlagshaus Monsenstein und Vannerdat, 2010); and Susan Fast and Kip Pegley, eds., Music, Politics E Violence (Middletown, CT: Wesleyan University Press, 2012).

${ }^{21}$ Most of my key informants stemmed from the former, more politicized group mentioned here. Therefore, I cannot exclude a slight bias towards more ideologically charged combatants' statements.

${ }^{22}$ I gathered my material through recorded and informal qualitative interviews in Kailahun, Bo, Kenema, Makeni and Freetown. I also interviewed several SLA soldiers, AFRC combatants, members of the Kamajors/CDF and civilians.

However, due to the constraints of space, I am focusing on findings gathered from up to 40 interviews I conducted with former RUF combatants in 2010/2011 and 2011/2012.

${ }^{23} \mathrm{My}$ research findings shall neither mitigate war violence nor exonerate my interlocutors from what they did during the war. Rather, my research tries to shed light on what galvanized youthful combatants and how they used music during the war.
} 
to roots reggae because they felt that this musical genre was particularly meaningful to them. Although roots reggae was and is generally popular among young people in West Africa, the former rebels pointed out that the genre experienced a newfound popularity and became increasingly prominent among them again at the beginning of and throughout the war.

In fact, roots reggae, coupled with pan-Africanist, Marxist, liberal, and other revolutionary writings, was already a prominent music genre among marginalized youth and students protesting against deplorable socioeconomic conditions created by the corrupt ruling government during the late 1970s. Music was an integral part of creative youth initiatives challenging hegemonic structures, and reggae in particular fuelled the mobilization of students to engage in university politics and public protest. The engagement with "conscious" music, as roots reggae is often described, also contributed to the development of a more revolutionary and radical political stance among disaffected youth. In many ways, the political resistance of radical students and marginalized youth foreshadowed the frustrations that also incited the coming war of the 1990s, and a number of youth activists were involved in the initial planning of launching a violent rebellion. ${ }^{24}$ Therefore, a lot of the RUF recruits typically had a more intuitive revolutionary consciousness, one notably shaped by reggae-style Rasta talk and demeanor. ${ }^{25}$

The centrality of reggae in Sierra Leonean subversive youth culture is further corroborated by the events of 1992. One year after the outbreak of the Sierra Leonean war, a group of military junior ranks well under thirty years of age overthrew the ruling government to establish the National Provisional Ruling Party (NPRC), aiming to end the war swiftly and return the country to political pluralism. The junta's takeover initially sparked spontaneous euphoria, particularly among urban, working-class youth who identified with the youthfulness of their new political rulers. In fact, Sierra Leonean youth and the junta leaders had similar backgrounds and referred to the same youth culture and music. The broadcast announcing the successful coup was accompanied by continuous reggae and rap music. Young Sierra Leoneans demonstrated their allegiance to their peers in power by exchanging Rastafarian salutes with the junta soldiers. Youth organizations flourished to celebrate the fresh political start, and a new wave of patriotism and support for the military leadership swept through the country. Valentine Strasser, 26-yearold head of the NPRC government, and other youthful figures of the upper echelons were idolized as heroes and martyrs in murals and other patriotic symbols. The emerging street art that could be seen all over Freetown displayed and combined depictions of junta members alongside popular music figures (such as Bob Marley and Peter Tosh), revolutionary heroes, and quotes of Rastafarian values and reggae song lyrics. For a short while, youth culture, music, popular music figures, and politics were consolidated in novel ways, putting commonly marginalized and disaffected youth and their lifestyles on the political map, propelling subcultural music into the cultural and political mainstream for the first time. After a couple of months, however, the momentum had waned and made way to general disappointment among youths who did not see their expectations met by the NPRC they had so fervently promoted, not least because the military junta came to resemble the very regime it had ousted. ${ }^{26}$

\footnotetext{
${ }^{24}$ See Abdullah, "Bush Path to Destruction"; Ismail Rashid, "Student Radicals, Lumpen Youth, and the Origins of Revolutionary Groups in Sierra Leone, 1977-1996," in Between Democracy and Terror: The Sierra Leone Civil War, ed. Ibrahim Abdullah, 66-89 (Dakar: CODESRIA, 2004); Abdullah and Muana, "The Revolutionary United Front of Sierra Leone"; Abdullah, "Youth Culture and Rebellion."

${ }^{25}$ Richards, No Peace, No War, 3.

${ }^{26}$ Joseph A. Opala, “'Ecstatic Renovation!' Street Art Celebrating Sierra Leone’s 1992 Revolution,” African Affairs 93 , no. 371 (1994): 195-218. See also Michael Stasik, DISCOnnections. Popular Music and Audiences in Freetown, Sierra Leone (Leiden: Leiden University Press, 2011).
} 
Meanwhile, behind rebel lines, reggae music was also popular with RUF combatants. Former RUF fighters suggested that the momentum roots reggae regained with the outbreak of the war stemmed from the fact that they could relate the issues mentioned in the songs to their own situation. They emphasized that reggae music carried a strong, critical message and that it was precisely this message that made them listen to reggae music in particular. This explanation may in part be linguistically grounded because Jamaican Patois and Sierra Leone's lingua franca, Krio, bear linguistic and structural similarities. Several former combatants pointed out that the reggae lyrics were well understood compared to, for example, rap music with its rather fast-paced and dense lyrics. The reggae songs were perceived to be more laid-back, and the lyrics were of a slower pace. Therefore the messages in the songs were more easily understood by the combatants and appealed to them in a more straightforward and pronounced fashion. More importantly, however, RUF combatants were attracted to roots reggae because of the centrality of its social critique, the prominent theme of socio-political oppression, and the recurring image of the sufferer, which not only allowed for recognizing their own marginality through songs but also motivated them and fuelled their determination to resist prevailing, hegemonic conditions. Two former RUF combatants describe the impact reggae music had on them during the $\operatorname{war}^{27}$ :

It educate us, it motivate us, it push we [us]. It can even give you ideas to [be] aware that you now need to be brave. ${ }^{28}$

Music was the only courage that we had. [...] So everyone has his own interpretation. [...] Yeah, so people give different interpretation to our musics, you know, everyone has his type desire that he rips from any music, really. [...] [T] he purpose of reggae music is the message, the message, it added to the political ideology that we were given to [on] the [training] base, really. ${ }^{29}$

Due to the lack of formal education and the consequently high illiteracy rates among many fighters, reggae songs may have provided an opportunity for informal learning and may have served as a substitute means of gaining knowledge about socioeconomic differences, thereby raising political awareness. ${ }^{30} \mathrm{~A}$ few former RUF interviewees pointed out that the rebel leader Foday Sankoh himself enjoyed listening to reggae music and therefore welcomed the listening habits of his combatants, since the reggae protest songs contributed to keeping up the morale and strengthening in-group cohesion. There is also evidence that in the initial stages of the war, RUF administrators and those responsible for spreading the word about the RUF agenda among civilians occasionally referred to reggae music and lyrics to get their message across; other times, RUF Physical Training Instructors not only introduced a number of commando and reggae songs but also used statements made in reggae songs to convey codes of conduct and to clarify issues during ideology training in camp. At the military base, combatants would introduce each other to reggae musicians and songs, sing along to the lyrics, discuss the songs, and thereby engage in musical and political (self-)socialization. When stationed near the second city Bo, RUF combatants enjoyed listening to the commercial radio station Bo Kiss FM, which mainly played reggae songs. This way they would learn about new artists and songs, and occasionally, rebels made song requests to radio stations so that they could listen

\footnotetext{
${ }^{27}$ I kept the wording of all quotes in favor of capturing the original tone and voice of my interlocutors. Occasionally, I add words or additional information in brackets for better comprehensibility.

${ }^{28}$ Interview with T., Kailahun, November 11, 2010.

${ }^{29}$ Interview with D., Kailahun, November 13, 2010.

${ }^{30}$ Christian McWhirter also mentions the importance of music as a form of schooling with regard to combatants' illiteracy rates during the American Civil War. Battle Hymns: The Power and Popularity of Music in the Civil War (Chapel Hill:

University of North Carolina Press, 2012).
} 
to all-time favorites again. ${ }^{31}$

My interlocutors also mentioned that the lyrics of reggae songs that were popular within the cadres were sometimes transformed to fit the RUF context. For instance, an excerpt of Bob Marley's lyrics for the song "War" are:

Rumours of the war
And until that day
The African continent
Will not know peace
We Africans will fight
We find it necessary
And we know we shall win
As we are confident
In the victory

The versions below show the RUF's slight and obvious changes to the lyrics, made in an attempt not only to appropriate the song for motivational purposes but also to claim more personal ownership over it. As a former combatant put it, "we start to get our own album in Bob Marley reggae music." 32 The rebel song versions were sung during moments of rest on the military base, but they also accompanied looting operations:

War, war, no matter war
And until that day
RUF will be in [at] peace
We RUF fighters will fight
We find it necessary
And we know we shall win
And we have confidence
In the victory

War, war, no matter war And until that day RUF will be in [at] peace We RUF fighters will fight We find it necessary And we know we shall win In the victory

Roots reggae is widely perceived as protest music and is associated with a critical commentary on moral and social issues, demanding political liberalization, equality, justice, unity, and freedom of speech. Already prior to the Sierra Leonean war, reggae music may have functioned as a mouthpiece through which perceptions of prevailing socioeconomic conditions could be voiced without the threat of severe reprisal imposed by oppressive systems. ${ }^{33}$ Its mobilizing rhetoric suggests subversive notions; its lyrics may be understood as a call for revolution and the downfall of established power structures. ${ }^{34}$ Many of the fighters recognized their own frustrations and perceived grievances in reggae songs and linked them to the aspirations of the RUF uprising. This way, reggae songs also affirmed and reaffirmed the reasons behind

\footnotetext{
${ }^{31}$ Paul Richards, "Broadcasting and the Musicology of War: The Case of Sierra Leone," in The Soundtrack of Conflict: The Role of Music in Radio Broadcasting in Wartime and Conflict Situations, ed. M. J. Grant and Férdia-Stone Davis (Hildesheim: Georg Olms Verlag, 2013), 171-172.

${ }^{32}$ Interview with M., Makeni, December 27, 2011.

${ }^{33}$ In the years leading up to the conflict, there was virtually no freedom of expression in Sierra Leone. Statements of political opposition were subject to legal punishment. I found no evidence, however, that reggae music was subject to censorship, either because it "slipped through" the censorship machinery (being a highly popular musical genre generally) or because music was not recognized as a tool to stir dissent or to have the potential to seriously undermine the government's authority. ${ }^{34}$ See, for example, Stephen A. King, Reggae, Rastafari, and the Rhetoric of Social Control (University Press of Mississippi, 2002); and King, "Protest Music as 'Ego-Enhancement': Reggae Music, the Rastafarian Movement and the Re-Examination of Race and Identity in Jamaica," in The Resisting Muse: Popular Music and Social Protest, ed. Ian Peddie (Aldershot: Ashgate, 2006); Dick Hebdige, Cut'n'mix: Culture, Identity and Caribbean Music (London: Routledge, 2005); Peter Manuel, Caribbean Currents: Caribbean Music from Rumba to Reggae (Philadelphia: Temple University Press, 2006).
} 
their participation in the revolutionary struggle and generated a martial mindset. A lot of the critical commentary in the songs resonated with the demands and the critique articulated within the RUF movement as well as in their published manifesto "Footpaths to Democracy."

Apart from Bob Marley, the most commonly played reggae musicians during the war were the South African artist Lucky Dube, Jamaican singer Burning Spear, and the Jamaican band Culture, spearheaded by Joseph Hill. RUF fighters particularly liked Joseph Hill because he was one of the few artists who regularly toured Sierra Leone, even in times of war, and who, with his band, dedicated songs like "War in Sierra Leone," released in 1999 to demand an end of the hostilities happening in the country. Hill's concerts during wartime literally effected ceasefires, with rebel combatants laying down their arms for the duration of his visit so that they could attend his concerts. ${ }^{35}$

RUF combatants regarded themselves as freedom fighters for a just cause. Lucky Dube's song "House Of Exile," released in 1992, confirmed these notions of fighting the good fight by adopting the image of the "freedom fighter." A former bodyguard to the rebel leader Foday Sankoh comments on his comrades' and his own listening habits:

Lucky Dube, "Freedom Fighter, Standing on a Mountain." Right? Fighting for freedom, trying to free his own people. It's like, these people [the Sierra Leonean population] have been under bondage. The people have been under bondage. But it is mandated to fight for his [their] right. It is like they [the RUF] have brought him [Lucky Dube] on board to fight for his [their] own right.

[...] Just like this music they found a freedom in those, I mean, this musics. They find a freedom, as if this music is their national anthem or the actual reason of why they are fighting. ${ }^{36}$

When further analyzing the song lyrics, there are several aspects that show certain parallels to the rebels' agenda and their perceived situation. Lucky Dube sings about a "freedom fighter" who sacrifices himself and leaves his home to spend his days in exile "for the love of the nation," dreaming of "the freedom of the nation" and fighting for a time "when every man will be equal in the eyes of the law." The song particularly resonated with the combatants once they shifted tactics from conventional target warfare to guerilla warfare. When the events of the war made it necessary for the movement to withdraw into the jungle, it was an experience that proved to be marked by deprivation for most of the fighters. Living conditions may have felt similar to those of living in exile, far away from one's homeland and the comforts of everyday life. The song may have helped to dissipate the rebels' felt isolation in the jungle retreat. The image of the "freedom fighter standing on a mountain in a foreign country" may have spoken to the rebels on another level as well. Since the combatants felt alienated in their home country due to political exclusion and lack of support from the civilian population, they may have felt as if they were living "in a foreign country." The image of the mountain in the song coincided with the movement's actual location and retreat into the mountainous jungle in Sierra Leone's heartland.

RUF fighters regarded reggae artists most highly. They described them as prophets, truth-tellers, preachers, advocates and social commentators. Apart from obvious examples such as Bob Marley's songs "Get up, Stand up for Your Right," "War," and “The Real Situation," Burning Spear's reggae album The

\footnotetext{
${ }^{35}$ Personal conversations with Freetown citizens. See also Claude Mills, "Joseph 'Culture' Hills Laid to Rest - 'I will only go if you put the gun down' (Sierra Leone)," Yardflex.com, September 10, 2006, http://www.yardflex.com/archives/000721.html; Joel Savage, "Tribute to the Great Joseph Hill of Culture," A Mixture of Periodicals (blog), November 2006, http://juskosave.blogspot.de/2006/11/tribute-to-great-joseph-hill-of.html.

${ }^{36}$ Interview with V., Freetown, February 2, 2010.
} 
World Should Know, released in 1993, was popular not only for its revolutionary songs but also for the fact that the first five track titles read in order became somewhat of a slogan for some of the interviewed RUF combatants. The order of the tracks reads as follows: "The World Should Know," "In a Time Like Now," "I Stand Strong," "Identity," "It's Not A Crime." Some further explanation was given by former combatants as to the first, fourth, and fifth song titles in particular. During the second phase of the war when the RUF had adopted guerilla tactics, new strategies and maneuvers emerged. Besides ambushes and hit-and-run raids, they sometimes executed false flag operations dressed in Sierra Leonean Army attire. Civilians thereupon struggled to identify who had actually attacked them. This way, RUF combatants not only tried to defy clear accountability; they also seemed to have found pleasure in confusing their victims about the attackers' real identity. ${ }^{37}$

Others suggested that their new status as rebel fighters provided for a new identity, which gave them the idea of regaining a sense of belonging and recognition in their home country. "It's Not A Crime," the fifth song of Burning Spear's album, often helped legitimize and justify casualties and other condemnable conduct as not being a crime since they were committed within the context of war. The following two statements by two former RUF combatants from Kailahun who both joined the movement in 1991 address a number of issues with regard to reggae songs and Burning Spear's album The World Should Know in particular:

Then, during the war, now, when the war came in 1991, those who came with the war were used to listen to Lucky Dube. Yes, like Prisoner, you know, then times to come, when we were advancing in the country, we were used to capture some cassettes like Burning Spear, The World Should Know, "Identity," you know, sometimes, when we were in the big towns, we capture these cassettes, we play, we feel that, you know, we are part of the country, "It's Not a Crime," you know, these are the musics we are listened to a lot, like Dube and Burning Spear and Culture, Lion Rock, Culture at Work, you know, sometimes, even in the battles some brave guys were used to get these Walkmen, playing hence, it is not in the dead zone, you know, we are used to transform it in different, different way. Because sometimes, it makes somebody, make bravery, you see. ${ }^{38}$

It [reggae's popularity] coincided with the intensity of the war. In the year 1993, you know, on the part of the RUF it was really difficult. ${ }^{39}[\ldots]$ [S]o some of this music, those songs gave us courage to really stay and challenge the situation-and that we did. Say The World Should Know, that is: we should now act for the entire world to know that we are still alive and that we have not been entirely crushed. So we loved those kind of music. The World Should Know. We managed to go through and listening to those songs we were able to manage the situation. Anyway, it was just a sort of coincidence that at that time of the revolution, those mu-, those numbers came in.

[...] So The World Should Know-you have to link it up with so many other things. Yeah, the world should know about my existence, the world should know, about what? The revolution, something like that. [laughs] And fighting, you know, when you are fighting war, there are certain things you cannot avoid entirely. That's what? Killing. You cannot avoid that entirely,

\footnotetext{
${ }^{37}$ Due to the fact that the Sierra Leonean regular army also committed atrocities against civilians, they were supposed to protect from the RUF insurgents, civilians coined the term sobel—soldiers by day, rebels by night— to indicate that it was no longer possible to distinguish friend from foe.

${ }^{38}$ Interview with T., Kailahun, November 11, 2010.

${ }^{39} \mathrm{M}$. refers to a phase in the war when the RUF was almost out of ammunition, had lost considerable parts of its control areas, and was nearly facing defeat.
} 
so when fighting is going on, killing occurs. So this is not a crime. What is not a crime? Killing, that killing maybe is not a crime. And [then] the other musician says "No Man Kills Another Man” [song by South African reggae musician Jambo]—what's going on? So... [laughs] I had pleasure listening to these sounds.

[...] Most of the sayings, like those phrases, the phrases we had in reggae, yes, inspired zeal, inspired zeal in most young men, to stay within [the RUF movement]. And they are smoking [marijuana] at the same time listening to reggae music keeps you in line with certain difficult situations like that. ${ }^{40}$

The interview excerpts inform us that reggae music was widely listened to among the combatants. Although a lot of the songs that were released during the 1990s would certainly have gained wider popularity in Sierra Leone in any case, some songs gained particular momentum with the RUF fighters because they resonated with actual circumstances and events within the war. Music recordings (and concomitantly batteries and solar panels) seem to have been desirable items rebels tried to get hold of through looting ("capture cassettes"), even though or especially because they were at war.

T. remembers that the bravest fighters would listen to music on their portable cassette players during combat action. This way, an accompanying soundtrack would distract them from the dangers at the frontline and fuel their bravery. Other interview accounts dealing with the same phenomenon emphasize the role of music as a means of "entrainment," facilitating desired bodily conduct and channeling focus. ${ }^{41}$ M. echoes aspects similar to what Keen articulates in relation to the RUF's ambition for the movement to be recognized ("The world should know, about what? The revolution"). ${ }^{42}$ Further, M. points out how the reggae lyrics induced zeal in the fighters, not only for military operations to come but for perseverance, encouraging them to stay with the movement even in difficult times. M. mentions smoking marijuana as an integral part of the listening experience. Not only did RUF combatants turn to reggae for advice and motivation and in order to cope with and justify their involvement in the movement, but they also took on aspects of the Rastafarian lifestyle such as smoking marijuana and adopting Rasta rhetoric and the dreadlock look. ${ }^{43}$

By describing the use of music as "transforming it in different ways," T. confirms the notion that music is subject to interpretation and "musical framing." 44 For many of the RUF combatants, music was an ally; the fighters were looking for the "me in music." In this way, musical properties were linked with the biographies of individuals. Music's powers, then, derive from and through the ways in which individuals orient themselves in relation to it, interact with it, and situate it within their own musical maps, within the fabric of music and extramusical associations. Music functions on what Middleton calls a "secondary signification" level, drawing the listener into a connotative (temporal) trajectory that he or she has constructed on the basis of ascribing perceived meanings to the musical material. ${ }^{45}$

It is interesting to note that the combatants' statements reveal diverse uses of the same songs, or at least the same musical genre, and the varied responses they had to them. Many accounts stress that reggae

\footnotetext{
${ }^{40}$ Interview with M., Kailahun, November 13, 2010.

${ }^{41}$ DeNora, Music in Everyday Life; Richard Middleton, Studying Popular Music (Milton Keynes, UK: Open University Press, 1990).

${ }^{42}$ David Keen, “'Since I Am a Dog, Beware of my Fangs': Beyond a 'Rational Violence' Framework in the Sierra Leonean War,” Crisis States Research Centre Working Papers Series 1, 14 (2002).

${ }^{43}$ Despite the fact that RUF combatants adopted some aspects of Rastafarian lifestyle, they did not seem to convert to Rastafarian socioreligious worldviews.

${ }^{44}$ DeNora, Music in Everyday Life.

${ }^{45}$ Middleton, Studying Popular Music.
} 
music was meaningful on many different levels and in different ways depending on what the listener "needed of the music" at a given moment in order to create a certain state of mind. ${ }^{46}$ Reggae songs could relax the fighters after battle and create a sense of normalcy in the middle of a war situation, but the songs could also motivate, generate zeal, and instill determination or provide (re-)affirmation and legitimization of their active involvement in conflict. Reggae music was never regarded as being violent, however. In fact, the opposite was the case. Combatants perceived reggae as "conscious music," which functioned as a sort of eye-opener, advising the listeners to fight for their right, thereby creating critical political awareness. Since the rebels linked perceived meanings and personal associations to the reggae messages, and since the reggae songs would not dictate the realization of self-empowerment in practice, the actual implementation of claiming one's right (in this case carried out by flagrant human rights violations) was not necessarily challenged by the combatants themselves or seen as contradictory to the advisory teachings they found within reggae songs. More likely, it seems that the political awareness gained through the consumption of reggae music was divorced from the brutal execution of the liberation struggle. Therefore, rebels did not feel any discrepancy between theory (reggae songs) and practice (violent war).

That reggae provided a considerable and meaningful source for the RUF combatants might suggest that music mostly had an impact due to the song lyrics. It is important to note the inseparability of music and lyrics, however. Music is a medium that communicates and operates semiotically, thus calling upon content and meaning beyond its lyrics. Certainly, reggae artists do compose songs because they want, for example, to critically expose social and political grievances, and combatants attentively listened to the rhetoric and specifically referred to the lyrics in interviews. Nevertheless, in so doing, they have precisely drawn upon musical structures as resources for organizing, mediating, and substantiating their selves and their own ideas of their situation and have thereby found ways to justify their conduct in war. At other times, however, examples from my research show that lyrics have been completely ignored and discarded or were simply not understood due to language barriers. In these cases, other properties of these songs were prioritized over lyrics. But this did not lessen the music's effect upon the combatants' engagement with the songs, not least since they chose to lend meaning to them. ${ }^{47}$

\section{Music of Oppression: The Rebels' Instrumentalization of Bubu Music}

Despite the ongoing war, local Sierra Leonean musicians continued producing songs and releasing albums for the local market. Some Mende-speaking artists such as Amie Kallon, Yusuf Gbetowah, and Steady Bongo commented on the events of the war, criticizing the perpetrators and addressing issues of displacement, looting, the destruction of property, and the suffering of the civilian population. The Temne-speaking musician Ahmed Janka Nabay also continued recording the typical music of his ethnic group, the so-called Bubu music. Janka Nabay is commonly considered the king or father of Bubu music and has vastly popularized the style not only in Sierra Leone but also internationally. He was the first to record Bubu and modernized the sound by using electronic studio instrumentation such as keyboards,

\footnotetext{
${ }^{46}$ See also Lisa Gilman, “An American Soldier's iPod: Layers of Identity and Situated Listening in Iraq,” Music E Politics 4, no. 2 (2010), http://dx.doi.org/10.3998/mp.9460447.0004.201; Jonathan Pieslak, Sound Targets: American Soldiers and Music in the Iraq War (Bloomington: Indiana University Press, 2009).

${ }^{47}$ RUF combatants enjoyed popular music from South Africa, Nigeria and Congolese zouk. See also my article on RUF commando songs which were largely borrowed from Liberian NPFL forces. Cornelia Nuxoll, "Borrowed Tunes. Commando and Moral Booster Songs of RUF Fighters in the Sierra Leone War," in "Musique et Conflits armés après 1945," special issue, Transposition. Musique et Sciences Sociales, no. 4 (2014), http://transposition.revues.org/598?lang=en.
} 
synthesizers, and drum computers to produce lively dance beats. Bubu was traditionally played for witchcraft ceremonies but later became part of popular Muslim processions during Ramadan, and it accompanies the country's independence day celebrations. An orchestra of bamboo flutes, carburetor pipes, and other metal tubes of different sizes, as well as large wooden boxes, shakers, cowbells, and triangles creates the distinctive, highly rhythmic, and fast-paced Bubu sound. ${ }^{48}$

Janka Nabay's music was popular not only among Sierra Leonean civilians but also with the RUF combatants. During the war, civilians who suffered direct encounters with the rebel insurgents witnessed terror operations involving Janka Nabay's music. ${ }^{49}$ RUF combatants regularly used Bubu music when invading villages and towns as part of hit-and-run raids. The rebels would play Janka Nabay's popular music from ghetto blasters in order to attract and lure out unsuspecting civilians for easy capture or forced conscription. At other times, rebels would create the impression of initiating a party, playing Bubu music from loudspeakers and inviting civilians to join in, only to later disclose their real motives and then capture them. ${ }^{50}$

You see, like in Kambia, [...] I have [know] an old woman. She can never forget this song because when they [the RUF] wanted to attack Kambia, they were playing this music on top of their head [carrying portable cassette players]. They [the rebels] enter the people's churches, just people happy, it was Christmas time. Festive time. So the people, all of them joined [the rebels' party] and they thought it's good, not knowing that after ten, fifteen minutes ... [the rebels were] everywhere. ${ }^{51}$

One song in particular was popular among the combatants as a rallying tool. The song "Wutupa" can be translated as "We are rallying" "52 and basically celebrates the success and popular appeal of Bubu music. During the war, however, the combatants changed Janka Nabay's song lyrics from "Bubu music has won this year" and "Baby come on, come and romance with me, let us dance to the Bubu music" to "The rebels have won this year" and "Baby come on, come and romance with us and dance with the rebels."

\footnotetext{
${ }^{48}$ See, for example, Andy Gensler, "No Cover: The Bubu King Janka Nabay," Soundcheck from WNYC, New York, August 21, 2010, http://soundcheck.wnyc.org/articles/music-hub/2010/aug/21/no-cover-janka-nabay/. Janka Nabay left Sierra Leone for the USA around the time when the war came to an end in his home country. In New York he re-established his musical career and started a new band called Fanka Nabay and the Bubu Gang. So far, he released three Afro fusion recordings (one solo EP, one 12-inch single release and one full-length album) based on the Bubu style with American record labels True Panther and Luaka Bop.

${ }^{49}$ Unfortunately, this section has fewer direct rebel quotes since they were more reluctant to speak about potentially condemnable strategies involving music than those that substantiated the political nature and the righteousness of their cause, as for example reggae did. Therefore, the information gathered here is predominantly compiled from witness accounts of civilians who experienced RUF attacks that involved music.

${ }^{50}$ Some online articles on Janka Nabay and Bubu music confirm this strategy. See, for example: "Quit your Day Job: Janka Nabay.” Interview with Janka Nabay by Stereogum, April 9, 2010, http://stereogum.com/332412/quit-your-day-job-jankanabay/franchises/quit-your-day-job/; John Muyskens, "Janka Nabay and the Bubu Gang," Calvin College website, accessed December 1, 2014, http://www.calvin.edu/sao/resources/artists/janka-nabay--the-bubu-gang.html; Jesse Jarnow, "Janka Nabay, the Bubu King, Grows in Brooklyn: A Sierra Leone superstar finds a new place to preach his country's musical gospel," Village Voice, November 10, 2010, http://www.villagevoice.com/2010-11-10/music/janka-nabay-the-bubu-king-growsin-brooklyn/; Mano Cockrum, "Rising Stars: Janka Nabay and the Bubu Gang," The Precarious.com, March 21, 2012, http://www.theprecarious.com/content/rising-stars-janka-nabay-and-bubu-gang; Luaka Bop, "Janka Nabay and the Bubu Gang's Full-length Debut En Yay Sah Finds the Futuristic Edge of a Ritual Flow," accessed December 1, 2014, http://luakabop.com/janka-nabay/; SXSW, Fanka Nabay and the Bubu Gang - "Ro Lungi": SXSW Music 2012, SXSW Interactive, 2012, accessed December 1, 2014, http://sxsw.com/janka-nabay-and-bubu-gang-ro-lungi-sxsw-music-2012. ${ }^{51}$ Interview with A., Makeni, December 29, 2011.

${ }^{52}$ In a radio feature, Janka Nabay describes Wutupa as "serious dancing" (see the NPR radio broadcast on Janka Nabay and the Bubu Gang on World Cafe from October 2012). An hour-long feature on Bubu, its history, and Nabay's biography titled Proving The Bubu Myth: Fanka Nabay, War and Witchcraft in Sierra Leone (2014) is available online via Afropop Worldwide: https://soundcloud.com/afropop-worldwide/proving-the-bubu-myth.
} 
When entering a settlement, the rebels would play loud music and sing their own version on top of the original lyrics. ${ }^{53}$

A Makeni resident remembers the RUF adaption of the Bubu song during operations, making specific references to the changed lyrics and the inversion of its meaning through rebel appropriation:

"Ah Bubu po win nay, kay da kay halo-ooo. Or bothi kay ra suay"-that is, you are saying: "The sweetness is going with him." He, the artist. "Baby malen, malen, malen" [...] [H]e is calling all the beautiful girls to come and join him to dance the Bubu because he has won [...]. "Ah wuth pa ay, ah Bubu ah wuth pa, su seh. Ah wuth pa." So he is rallying, he is rallying. He has won them [the beautiful girls].

Referring to the RUF adaptation of the song and how it substantiates the impact of their actions during looting operations, he explains:

They [the RUF] change the lyrics of the artist; they put their own words. They change the tone, the tone now of the artist. [...] "Ah rebel ah po win nay, kay da kay halo-ooo. Or bothi kay ra suay," that the sweetness has gone with them. That they have captured the place; they have all the women now, all the money, everything that is there. So now they are enjoying the sweetness, the "Or bothi kay ra suay," so that the sweetness is going also. ${ }^{54}$

When Bubu musician Janka Nabay learned about the appropriation of the Wutupa song, he released the hit song "Sabanoh" in the mid-nineties to counter the rebels' ploy and to side with and empower the civilian population. ${ }^{55}$ The song loosely translates as "This country, we own here" or "This country belongs to us," claiming that Sierra Leone belongs to its peaceful citizens despite all rebel attempts to destabilize it and create chaos and anarchy. A female civilian from Kono who had fled to the capital city to escape RUF attacks in the provinces witnessed the Freetown invasion in 1999 and recounts how rebels once again appropriated Nabay's music, entering the capital with portable stereos on their heads, blaring Bubu songs into the fleeing crowds. Threatened with death or having their houses burned down, captured civilians were forced to sing along to the very song "Sabanoh" and other songs praising the RUF leader Foday Sankoh. ${ }^{56}$

Janka Nabay's "Wutupa" is a powerful example of how a popular song can be easily transformed by means of minor changes to the lyrics. The RUF version of "Wutupa" now claims victory for the RUF and prompts civilians to celebrate and join the rebel movement, thereby turning the message around completely and transforming it into an intimidating and threatening song.

People are scared of the music now. When they hear[d] it, it's: "Hey! Maybe the guys [the RUF] are coming."

Most times civilians don't play it again [anymore] that time. They were scared of the music. Very nice song. But they were scared of playing, singing it now. ${ }^{58}$

The RUF utilized not only recorded music during or in preparation for attacks. Sometimes traditional

\footnotetext{
${ }^{53}$ The blockbuster movie Blood Diamond recounting the Sierra Leonean war and the film fohnny Mad Dog depicting the Liberian war both show scenes of rebel attacks involving music.

${ }^{54}$ Interview with T., Makeni, December 29, 2011.

${ }^{55}$ Ahmed Janka Nabay's song "Sabanoh" (Side A, Track 4) can be listened to, as part of Oliver Rivard's article "Janka Nabay's Sabanoh Tape MP3 + Help the Bubu Man.” Fader, March 8, 2011 at http://www.thefader.com/2011/03/08/jankanabays-sabanoh-tape-mp3-help-the-bubu-man/.

${ }^{56}$ Interview with K, Makeni, December 29, 2011.

${ }^{57}$ Interview with A., Makeni, December 29, 2011.

${ }^{58}$ Interview with T., Makeni, December 29, 2011.
} 
drum ensembles accompanied RUF troops and played for the insurgents during targeting operations. This was done to lower civilian resistance or cause them to vacate the premises, thereby facilitating the looting of material goods. In Kailahun district not only did the local Pandajuma Cultural Band ${ }^{59}$ entertain the rebel troops after operations but their drumming was also instrumentalized as a tool of deception. A former RUF combatant recruited in Kailahun district remembers that drums were played in the bush while they were advancing towards civilian settlements:

We would implement it, those type [of] drum. And that drum, we hit that drum. Bo-boom ... Boom. You will think that we use heavy artillery, [but in fact it was] not heavy artillery, yeah. We use drums so that people will panic, they will leave the grounds. So when we hit the drum, they will leave the ground. When they leave the ground, we capture the ground. We take logistics and go back, to [the military] base. ${ }^{60}$

The weaponization of Bubu music and traditional drums shows how combatants controlled the soundscape of their target areas by resorting to "acoustic violence" ${ }^{61}$ or "musical violence." music as a soundtrack to accompany guerilla operations, the insurgents may have appeared more omnipresent to their victims. The sound wall may have added considerably to the disorientation and despair among fleeing victims and may have worsened the traumatic experience of the civilians under attack.

Without changing any lyrics but by using the "Sabanoh" song against the very people it was originally composed for, RUF combatants demoralized and humiliated their victims by forcing them to sing along to a song that had, through the rebels' appropriation, received an inverted meaning. ${ }^{63}$ The rebels practically robbed the civilians of "their song" by perverting its message. The RUF's deliberate strategy to instrumentalize, misappropriate, and recontextualize music as weapon, ${ }^{64}$ or music as an accomplice of violence, contributed considerably to the incitement of fear and terror among their victims. ${ }^{65}$

Other examples confirmed this strategy and described how civilians, under gunpoint and as witnesses and victims of extreme violence, were sometimes forced to sing songs, make music, or dance for

\footnotetext{
${ }^{59}$ Another spelling is "Bandajuma." There are inconsistent stories on the Pandajuma Cultural Band with regard to their involvement with the RUF. While some interlocutors stated that the band voluntarily joined the rebel cadres as music entertainers and occasionally even as combatants, others claim that they were forcefully recruited into the service of the insurgency and only played for the RUF as a means of self-preservation. I spoke with one of the musicians and he claimed forced recruitment, although some of his statements occasionally suggested otherwise. Claiming forced recruitment may have been a comprehensible strategy to escape stigmatization.

${ }^{60}$ Interview with M., Makeni, December 29, 2011.

${ }^{61}$ Juliane Brauer, Musik im Konzentrationslager Sachsenhausen, Schriftenreihe der Stiftung Brandenburgischer Gedenkstätten, Band 25 (Berlin: Metropol Verlag, 2008).

${ }^{62}$ Johnson and Cloonan, Dark Side of the Tune; Pieslak, Sound Targets.

${ }^{63}$ Sierra Leonean journalist Claudia Anthony describes a similar incident during the Freetown invasion in 1999. She was among civilians who were forced to sing "We want peace!." In front of rebels, they were lined up and had to clap and sing like schoolchildren. When underage combatants, the main perpetrators of atrocities during the Freetown invasion and therefore the most feared during the attack, appeared on the scene, the singing and clapping became even more intense and the singing of the chorus continued in a higher pitch. "Attacks on the Press 1999: The Trauma of Sierra Leone," Committee to Protect Journalists, March 22, 2000, http://cpj.org/x/1dcb.

${ }^{64}$ Cusick, "Music as Torture/Music as Weapon."

${ }^{65}$ The utilization of music as a means of humiliation, terror, and torture is an effective strategy well known from other conflicts. For examples from the Third Reich see, e.g., Guido Fackler, "Music in Concentration Camps 1933-1945," trans. Peter Logan, Music \& Politics 1, no. 1 (2007), http://dx.doi.org/10.3998/mp.9460447.0001.102; and Shirli Gilbert, Music in the Holocaust: Confronting Life in the Nazi Ghettos and Camps (Oxford: Oxford University Press, 2005). See also Anna Papaeti's work on music torture during the Greek Junta (1967-74) investigating the use of music in no-touch torture as part of the detention and interrogation of political prisoners and exiled detainees: "Music, Torture, Testimony: Reopening the Case of the Greek Junta (1967-1974)," in "Music and Torture | Music and Punishment," ed. M.J. Grant and Anna Papaeti, special issue, The World of Music (new series) 2, no. 1 (2013): 67-89.
} 
the RUF insurgents. The coerced performances would often prepare, lead up to, and accompany the execution of atrocities. Failure to comply would result in the immediate killing of the person in question. During the Freetown invasion, captured civilians were also forced to sing peace and praise songs to claim their support of and loyalty to the joint AFRC/RUF junta. Other sources report how rebels would mark their presence and forcibly demand recognition in civilian settlements by singing songs while they were looting and destroying civilian property. ${ }^{66}$

Music continued to play a central role in post-conflict Sierra Leone in the context of reconciliation and local cleansing rituals facilitating the reintegration of former combatants back into their communities. Local popular musicians were commissioned within the context of UN programs and NGO projects to compose songs promoting peace and nation building, spreading the message on rallying trips throughout the country. The postwar period between 2002 and 2007, culminating in the first postwar elections, witnessed the upsurge of locally produced political music. Unprecedentedly, young musicians openly addressed and exposed the most pivotal political issues and expressed prevailing grievances such as political corruption and poor livelihood prospects for young people. The rebellious, outspoken, critical, and often satirical character of this new locally produced youth music provided an informal but inescapable space for social action and political education, mobilization, and opposition. Through music, youth found a conduit for political self-empowerment, claiming new spaces of freedom of expression and critical awareness. Ultimately, political youth music was not immune to being incorporated into the running election campaigns, and musicians were suspected of being bribed and co-opted to become praise singers for one of the two major political parties. ${ }^{67}$ With the artists' authenticity in question, the post-election period saw not only youth's disillusionment with politics and politicized music but also a turn to more "profane" love music. ${ }^{68}$ Given that many issues that fuelled the war remain largely unaddressed in post-war Sierra Leone, recent developments now suggest, that youth have shown a renewed interest in American gangsta rap and its violent aesthetics as a preferred form of self-expression, reflecting their desire for upward social mobility and being connected to global markets and trends. ${ }^{69}$

\section{Closing Remarks}

Focusing on the music and functionality of music during the war, the examples above show the many ways music was utilized during the course of the civil war or, rather, music's fluidity and equivocality when applied within interpretative schemes. Among RUF combatants, music listening was a shared and collective experience as well as a means of private meditation, negotiation, and construction of the self in war. Music helped to bolster identities, create a shared mental state and prompted a certain state of mind needed to manage, cope with, and make sense of the experience of war. Music provides multiple

\footnotetext{
${ }^{66}$ Alison Smith, Catherine Gambette, and Thomas Longley, Conflict Mapping in Sierra Leone: Violations of International Humanitarian Law from 1991 to 2002 (Sierra Leone: No Peace Without Justice, 2004), 36, 176, 195, 200, 435, 543, http://www.npwj.org/ICC/Conflict-Mapping-Sierra-Leone-Violations-International-Humanitarian-Law-1991-2002.html.

${ }^{67}$ Susan Shepler, "Youth Music and Politics in Post-War Sierra Leone," Fournal of Modern African Studies 48 (2010): 627-642; Zubairu Wai, "The Role of Youths and the Sierra Leone Diaspora in Democratic Awakening," in The Quest for Sustainable Democracy, Development and Peace: The 2007 Sierra Leone Elections, ed. A. B. Zack-Williams, 37-63 (Uppsala: Nordiska Afrikainstitutet, 2008); Sylvanus N. Spencer, "The Use of Pop Songs by Sierra Leonean Youths in Enjoying the Space Created for Freedom of Expression after the Civil War," Africa Today 59, no. 1 (2012): 71-86.

${ }^{68}$ Stasik, DISCOnnections.

${ }^{69}$ Boima Tucker, "Musical Violence. Gangsta Rap and Politics in Sierra Leone," Current African Issues, no. 52 (Uppsala: Nordiska Afrikainstitutet, 2013).
} 
identities, serving different functions in the day-to-day experience of armed conflicts depending on the social and emotional needs of a given moment. In the Sierra Leonean context it may have helped to manage emotions of fear and create zeal. Music was used to inspire and motivate combatants to take part in the liberation struggle. In some cases, it may have functioned as a justification for their active paramilitary involvement and their actions therein. The selective and interpretative listening to reggae songs forged cohesion and a sense of brotherhood among the fighters who linked the objectives of the RUF rebellion to reggae's call to claim one's right.

As Lisa Gilman, among others, aptly puts it: "Identification is necessarily tied to differentiation." Whatever binds people to a common cause or idea will differentiate and divide them from the Other, in this case a common enemy. Furthermore, Gilman rightly points out that the combatants' use of music is a lot more complex than, and goes far beyond, the depiction of "soldiers as brutes listening to brute music to be even more brutish." 71

The implementation of local Sierra Leonean songs as an acoustic weapon of terror and oppression served multiple purposes at the same time. Sonic bombardment not only worked as a means to lure people out for easy capture; its loudness also contributed to the exhaustion of its victims and the arousal of panic, fear, and disorientation. As Middleton rightly suggests, drawing on Adorno and others, the ear, unlike the eye, is always open. ${ }^{72}$ The ear is therefore constantly active and ready to engage in "participation." At the same time, it is less selective and more easily subjected to involuntary stimulus. By blasting their victims with music, RUF combatants seized and marked territory, occupied space, and created the impression of ubiquity. But the deliberate choice of music, the misappropriation of popular Janka Nabay's songs, points beyond the utilization of music as a sheer means of terrorizing with sound. By recontextualizing the songs' popular value and, as in the "Sabanoh" case, by overwriting its critical message towards the war and by subjecting victims to forced singing, these strategies of "musical sadism" "73 may have contributed to the erosion of the victim's sense of self and the weakening of their subjectivity. Music accompanying the execution of atrocities may be an attempt to further mask the severity of the war crimes committed, to render atrocities harmless, and to neutralize them against the backdrop of music to eventually distort them to absurdity.

More research will be needed to fully understand the diverse uses of music in armed conflict settings. In such research, special attention should be paid to what is distinct about music, and what therefore possibly makes it more powerful when it is taken out of its everyday use and employed within situations of war and violence. Music continues to be a pivotal tool for postwar Sierra Leonean youth(ex-)combatants or not-to negotiate their sociopolitical position in society by eking out spaces of enjoyment, self-expression, and dissent. In this regard, music may be a significant indicator for young people's marginalization, a means of self-administered othering, and music may assist in young people's peaceful and violent attempts to make their sociopolitical claims heard by their elders.

\footnotetext{
${ }^{70}$ Lisa Gilman, “An American Soldier's iPod: Layers of Identity and Situated Listening in Iraq,” Music E Politics 4, no. 2 (2010): 2, http://dx.doi.org/10.3998/mp.9460447.0004.201.

${ }^{71}$ Ibid., 6.

${ }^{72}$ Middleton, Studying Popular Music, 94; Theodor W. Adorno, Introduction to the Sociology of Music (New York: Seabury Press, 1976).

${ }^{73}$ A term coined by Aleksander Kulisiewicz, a survivor of the concentration camp Sachsenhausen, to describe NS-strategies in concentration camps that subjected prisoners to cruel, humiliating, and dehumanizing treatment while they were forced to sing songs. These songs often stood in stark contrast to the situation they found themselves in and for this reason increased their sense of despair and hopelessness (as stated in Brauer, Musik im Konzentrationslager Sachsenhausen, 99).
} 


\section{Bibliography}

Abdullah, Ibrahim, ed. Between Democracy and Terror: The Sierra Leone Civil War. Dakar: CODESRIA, 2004.

—_. "Bush Path to Destruction: The Origin and Character of the Revolutionary United Front/Sierra Leone." Journal of Modern African Studies 36, no. 2 (1998): 203-235.

http://dx.doi.org/10.1017/S0022278X98002766.

__. "Youth Culture and Rebellion: Understanding Sierra Leone's Wasted Decade." Critical Arts 16, no. 2 (2002).

Abdullah, Ibrahim, and Patrick Muana. "The Revolutionary United Front of Sierra Leone: A Revolt of the Lumpenproletariat.” In African Guerillas, ed. Christopher Clapham, 172-193. Oxford: James Currey, 1998.

Adorno, Theodor W. Introduction to the Sociology of Music. New York: Seabury Press, 1976.

Anthony, Claudia. "Attacks on the Press 1999: The Trauma of Sierra Leone," Committee to Protect Journalists, March 22, 2000. http://cpj.org/x/1dcb.

Brauer, Juliane. Musik im Konzentrationslager Sachsenhausen. Schriftenreihe der Stiftung Brandenburgischer Gedenkstätten, Band 25. Berlin: Metropol Verlag, 2008.

Brett, Rachel, and Irma Specht. Young Soldiers: Why They Choose to Fight. Boulder: Lynne Rienner Publications, 2004.

Cockrum, Mano. "Rising Stars: Janka Nabay and the Bubu Gang." The Precarious.com, March 21, 2012. http://www.theprecarious.com/content/rising-stars-janka-nabay-and-bubu-gang.

Cohn, Ilene, and Guy S. Goodwin-Gill, eds. Child Soldiers: The Role of Children in Armed Conflicts. Oxford University Press, 1994.

Collier, Paul, and Anke Hoeffler. "Greed and Grievance in Civil War." The World Bank Policy Research Working Paper 2355. World Bank, 2000. http://dx.doi.org/10.1596/1813-9450-2355.

Cusick, Suzanne. "Music as Torture/Music as Weapon.” Transcultural Music Review 10 (2006). http://www.sibetrans.com/trans/a152/music-as-torture-music-as-weapon.

_ . "You Are in a Place That Is out of the World . . ': Music in the Detention Camps of the 'Global War on Terror." Journal of the Society for American Music 2, no. 1 (2008): 1-26.

DeNora, Tia. After Adorno: Rethinking Music Sociology. Cambridge: Cambridge University Press, 2003. http://dx.doi.org/10.1017/CBO9780511489426.

—. Music-In-Action: Selected Essays in Sonic Ecology. Aldershot: Ashgate, 2011.

—. Music in Everyday Life. Cambridge: Cambridge University Press, 2000.

Denov, Myriam. Child Soldiers: Sierra Leone's Revolutionary United Front. Cambridge: Cambridge University Press, 2010. http://dx.doi.org/10.1017/CBO9780511676475.

Dupuy, Kendra E., and Krijn Peters. War And Children: A Reference Handbook. Santa Barbara: ABC Clio, 2010.

Fackler, Guido. "Music in Concentration Camps 1933-1945." Trans. Peter Logan. Music \& Politics 1, no. 1 (2007). http://dx.doi.org/10.3998/mp.9460447.0001.102.

Fast, Susan, and Kip Pegley. Music, Politics \& Violence, eds. Middletown, CT: Wesleyan University Press, 2012.

Fiske, John. Reading the Popular. London: Routledge, 1989. 
Frith, Simon "Music and Identity." In Questions of Cultural Identity, ed. Stuart Hall and Paul du Gay, 108127. London: Sage Publications, 1996.

Performing Rites: Evaluating Popular Music. Oxford: Oxford University Press, 1996.

Gberie, Lansana. A Dirty War in West Africa: The R.U.F. and the Destruction of Sierra Leone. London: C. Hurst \& Co. Ltd., 2005.

Gensler, Andy. "No Cover: The Bubu King Janka Nabay.” Soundcheck from WNYC, New York, August 21, 2010. http://soundcheck.wnyc.org/articles/music-hub/2010/aug/21/no-cover-janka-nabay/.

Gilbert, Shirli. Music in the Holocaust: Confronting Life in the Nazi Ghettos and Camps. Oxford: Oxford University Press, 2005.

Gilman, Lisa. "An American Soldier's iPod: Layers of Identity and Situated Listening in Iraq.” Music E Politics 4, no. 2 (2010). http://dx.doi.org/10.3998/mp.9460447.0004.201.

Grant, M. J. "Musik im Dienst des Massenmords." In Musik und Gewalt (Berichte aus dem Nationalkomitee Deutschland im International Council for Traditional Music XIX), ed. Marianne Bröcker, 259-268. Münster: Verlagshaus Monsenstein und Vannerdat, 2010.

Hebdige, Dick. Cut'n'mix: Culture, Identity and Caribbean Music. London: Routledge, 2005.

Hirsch, Lily E. "Do You Really Want to Hurt Me? Music as Punishment in the United States Legal System." Popular Music and Society 34, no. 1 (2011), 35-53. http://dx.doi.org/10.1080/03007766.2011.539818.

_- "Weaponizing Classical Music: Crime Prevention and Symbolic Power in the Age of Repetition." Journal of Popular Music Studies 19, no. 4 (2007): 342-358. http://dx.doi.org/10.1111/j.15331598.2007.00132.x.

Hoffman, Danny. The War Machines: Young Men and Violence in Sierra Leone and Liberia. Cultures and Practice of Violence. Durham, NC: Duke University Press, 2011. http://dx.doi.org/10.1215/9780822394488.

Honwana, Alcinda, and Filip de Boeck, eds. Makers and Breakers: Children and Youth in Postcolonial Africa. Oxford: James Currey, 2005.

Jarnow, Jesse. "Janka Nabay, the Bubu King, Grows in Brooklyn: A Sierra Leone superstar finds a new place to preach his country's musical gospel.” Village Voice, November 10, 2010. http://www.villagevoice.com/2010-11-10/music/janka-nabay-the-bubu-king-grows-in-brooklyn/.

Johnson, Bruce, and Martin Cloonan. Dark Side of the Tune: Popular Music and Violence. Aldershot: Ashgate, 2008.

—_ "Killing Me Softly with His Song: An Initial Investigation into the Use of Popular Music as a Tool of Oppression." Popular Music 21, no. 1 (2002): 27-39.

Kaplan, Robert D. The Ends of the Earth: A Journey at the Dawn of the 21st Century. New York: Random House, 1996.

Keen, David. Conflict and Collusion in Sierra Leone. Oxford: James Currey, 2005.

. " “Since I Am a Dog, Beware of my Fangs': Beyond a 'Rational Violence' Framework in the Sierra Leonean War." Crisis States Research Centre Working Papers Series 1, 14 (2002). London School of Economics and Political Science. http://eprints.lse.ac.uk/28296/.

King, Nathaniel. Conflict as Integration: Youth Aspiration to Personhood in the Teleology of Sierra Leone's 'Senseless War.' Uppsala: Nordiska Afrikainstitutet, 2007. 
King, Stephen A. "Protest Music as 'Ego-Enhancement': Reggae Music, the Rastafarian Movement and the Re-Examination of Race and Identity in Jamaica." In The Resisting Muse: Popular Music and Social Protest, ed. Ian Peddie, 105-118. Aldershot: Ashgate, 2006.

. Reggae, Rastafari, and the Rhetoric of Social Control. University Press of Mississippi, 2002.

Luaka Bop. "Janka Nabay and the Bubu Gang's Full-length Debut En Yay Sah Finds the Futuristic Edge of a Ritual Flow.” Accessed December 1, 2014. http://luakabop.com/janka-nabay/.

Machel, Graça. "Impact of Armed Conflict on Children." United Nations document A/56/306, August 26, 1996. http://www.unicef.org/graca/.

Manuel, Peter. Caribbean Currents. Caribbean Music from Rumba to Reggae. Philadelphia: Temple University Press, 2006.

McWhirter, Christian. Battle Hymns: The Power and Popularity of Music in the Civil War. Chapel Hill: University of North Carolina Press, 2012. http://dx.doi.org/10.5149/9780807882627_mcwhirter.

Middleton, Richard. Studying Popular Music. Milton Keynes, UK: Open University Press, 1990.

Miller, Richard. Review of "Eh Congo" by Janka Nabay (Bubu King EP). Dusted, March 18, 2010. http://www.dustedmagazine.com/reviews/5596.

Mills, Claude. "Joseph 'Culture' Hills Laid to Rest - 'I will only go if you put the gun down' (Sierra Leone).”Yardflex.com, September 10, 2006. http://www.yardflex.com/archives/000721.html.

Muyskens, John. "Janka Nabay and the Bubu Gang." Calvin College website. Accessed December 1, 2014. http://www.calvin.edu/sao/resources/artists/janka-nabay--the-bubu-gang.html.

Nabay, Janka. "Quit your Day Job: Janka Nabay.” Interview by Stereogum, April 9, 2010. http://stereogum.com/332412/quit-your-day-job-janka-nabay/franchises/quit-your-day-job/.

Nuxoll, Cornelia. "Borrowed Tunes: Commando and Moral Booster Songs of RUF Fighters in the Sierra Leone War." In "Musique et Conflits armés après 1945," special issue, Transposition. Musique et Sciences Sociales, no. 4 (2014). http://transposition.revues.org/598?lang=en.

O'Connell, John Morgan, and Salwa El-Shawan Castelo-Branco. Music and Conflict. Chicago: University of Illinois Press, 2010.

Opala, Joseph A. “'Ecstatic Renovation!' Street Art Celebrating Sierra Leone’s 1992 Revolution.” African Affairs 93, no. 371 (1994): 195-218.

Papaeti, Anna. "Music, Torture, Testimony: Reopening the Case of the Greek Junta (1967-1974)." In "Music and Torture | Music and Punishment," ed. M.J. Grant and Anna Papaeti, special issue, The World of Music (new series) 2, no. 1 (2013): 67-89.

Peddie, Ian, ed. The Resisting Muse: Popular Music and Social Protest. Aldershot: Ashgate, 2006.

Peters, Krijn. War and Crisis of Youth in Sierra Leone. International African Library. Cambridge: Cambridge University Press, 2011. http://dx.doi.org/10.1017/CBO9780511976896.

Peters, Krijn, and Paul Richards. "Youths in Sierra Leone: 'Why We Fight." Africa: Journal of the International African Institute 68, no. 2 (1998): 183-210. http://dx.doi.org/10.2307/1161278.

Peters, Krijn, Paul Richards, and Koen Vlassenroot. "What Happens to Youth During and After Wars?: A Preliminary Review of Literature on Africa and an Assessment of the Debate." RAWOO working paper, October 2013. http://dspace.library.uu.nl/handle/1874/2898.

Pieslak, Jonathan. Sound Targets: American Soldiers and Music in the Iraq War. Bloomington: Indiana University Press, 2009. 
Prestholdt, Jeremy. "The Afterlives of 2Pac: Imagery and Alienation in Sierra Leone and Beyond." Journal of African Cultural Studies 21, no. 2 (2008): 197-218. http://dx.doi.org/10.1080/13696810903259418.

Rashid, Ismail. "Student Radicals, Lumpen Youth, and the Origins of Revolutionary Groups in Sierra Leone, 1977-1996." In Between Democracy and Terror: The Sierra Leone Civil War, ed. Ibrahim Abdullah, 66-89. Dakar: CODESRIA, 2004.

Richards, Paul. "Against Ethnicity - Some Anthropological Arguments." Paper presented at "Rethinking Ethnicity and Ethnic Strife: Multidisciplinary Perspectives," conference at Central European University, Budapest September 25-27, 2008.

__. "Anarchists or Catalysts?” West Africa, February 20-26, 1995, 265-266.

-. "Broadcasting and the Musicology of War: The Case of Sierra Leone." In The Soundtrack of Conflict: The Role of Music in Radio Broadcasting in Wartime and Conflict Situations, ed. M. J. Grant and Férdia-Stone Davis, 167-184. Hildesheim: Georg Olms Verlag, 2013.

—_. "Emotions at War: A Musicological Approach to Understanding Atrocity in Sierra Leone." In Public Emotions, ed. Perri 6, Susannah Radstone, Corinne Squire, and Amal Treacher, 62-84. Basingstoke: Palgrave, 2007.

- Fighting for the Rainforest: War, Youth and Resources in Sierra Leone. Oxford: James Currey for the International African Institute, 1996.

, ed. No Peace, No War: An Anthropology of Contemporary Armed Conflicts. Oxford: James Currey, 2005. -. "The Social Life of War: Rambo, Diamonds and Young Soldiers in Sierra Leone." Track Two 8, no. 1 (1999). http://reference.sabinet.co.za/webx/access/electronic_journals/track2/track2_v8_n1_a5.htm.

Rivard, Oliver. "Janka Nabay's Sabanoh Tape MP3 + Help the Bubu Man.” Fader, March 8, 2011. http://www.thefader.com/2011/03/08/janka-nabays-sabanoh-tape-mp3-help-the-bubu-man/.

Rosen, David M. Armies of the Young: Child Soldiers in War and Terrorism. New Brunswick, NJ: Rutgers University Press, 2005.

Savage, Joel. "Tribute to the Great Joseph Hill of Culture." A Mixture of Periodicals (blog), November 2006. http://juskosave.blogspot.de/2006/11/tribute-to-great-joseph-hill-of.html.

Shepler, Susan. "Youth Music and Politics in Post-War Sierra Leone." Journal of Modern African Studies 48 (2010): 627-642. http://dx.doi.org/10.1017/S0022278X10000509.

Singer, P. W. Children at War. Berkeley: University of California Press, 2006.

Sloboda, John. "Empirical Studies of Emotional Response to Music." In Cognitive Bases of Musical Communication, ed. Mari Riess Jones and Susan Holleran, 33-46. Washington, DC: American Psychological Association, 1992. http://dx.doi.org/10.1037/10104-003.

- Exploring the Musical Mind: Cognition, Emotion, Ability, Function. Oxford: Oxford University Press, 2004.

- "Music Structure and Emotional Response: Some Empirical Findings." Psychology of Music 19, no. 2 (1991): 110-120. http://dx.doi.org/10.1177/0305735691192002.

Smith, Alison, Catherine Gambette, and Thomas Longley. Conflict Mapping in Sierra Leone: Violations of International Humanitarian Law from 1991 to 2002. Sierra Leone: No Peace Without Justice, 2004. http://www.npwj.org/ICC/Conflict-Mapping-Sierra-Leone-Violations-International-HumanitarianLaw-1991-2002.html. 
Sommers, Marc. "Peace Education and Refugee Youth." In Learning for a Future: Refugee Education in Developing Countries, ed. Jeff Crisp, Christopher Talbot, and Diane B. Cipollone, 163-216. United Nations High Commissioner for Refugees, 2001. http://www.unhcr.org/3b8a1bd84.pdf.

- Youth and Conflict: A Brief Review of Available Literature. USAID, Education Development Center, EQUIP3/Youth Trust, 2006. http://www.eldis.org/vfile/upload/1/document/0708/DOC22167.pdf.

Spencer, Sylvanus N. "The Use of Pop Songs by Sierra Leonean Youths in Enjoying the Space Created for Freedom of Expression after the Civil War.” Africa Today 59, no. 1 (2012): 71-86. http://dx.doi.org/10.2979/africatoday.59.1.71.

Stasik, Michael. DISCOnnections. Popular Music and Audiences in Freetown, Sierra Leone. Leiden: Leiden University Press, 2011.

SXSW. Janka Nabay and the Bubu Gang - "Ro Lungi": SXSW Music 2012. SXSW Interactive, 2012. Accessed December 1, 2014. http://sxsw.com/janka-nabay-and-bubu-gang-ro-lungi-sxsw-music2012.

Truth and Reconciliation Commission. Witness to Truth: Report of the Sierra Leone Truth E Reconciliation Commission. Vol. 3A. 2004. http://sierraleonetrc.org/index.php/view-the-final-report/table-ofcontents.

Tucker, Boima. "Musical Violence. Gangsta Rap and Politics in Sierra Leone." Current African Issues, no. 52. Uppsala: Nordiska Afrikainstitutet, 2013. http://nai.diva-portal.org/smash/get/diva2:618529/FULLTEXT01.pdf.

Turino, Thomas. Music as a Social Life: The Politics of Participation. University of Chicago Press, 2008.

Urbain, Olivier, ed., Music and Conflict Transformation: Harmonies and Dissonances in Geopolitics. Toda Institute Book Series on Global Peace and Policy. London: I.B. Tauris, 2008.

Utas, Mats. "Abject Heroes: Marginalised Youth, Modernity and the Violent Pathways of the Liberian Civil War.” In Years of Conflict: Adolescence, Political Violence and Displacement, ed. Jason Hart, 111-138. New York: Berghahn Books, 2008.

__ "Sweet Battlefields: Youth and the Liberian Civil War." PhD diss., Uppsala University, 2003. http://www.diva-portal.org/smash/get/diva2:163000/FULLTEXT01.pdf.

Utas, Mats, and Magnus Jörgel. "The West Side Boys: Military Navigation in the Sierra Leone Civil War." Journal of Modern African Studies 46, no. 3 (2008): 487-511.

http://dx.doi.org/10.1017/S0022278X08003388.

Van Kessel, Ineke, and Jon Abbink, eds. Vanguard or Vandals: Youth, Politics and Conflict in Africa. Leiden: Brill Academic, 2004.

Wai, Zubairu. "The Role of Youths and the Sierra Leone Diaspora in Democratic Awakening." In The Quest for Sustainable Democracy, Development and Peace: The 2007 Sierra Leone Elections, ed. A. B. ZackWilliams, 37-63. Uppsala: Nordiska Afrikainstitutet, 2008.

Wessells, Michael. "Recruitment of Child Soldiers in Sub-Saharan Africa: An Ecological Analysis." In The Comparative Study of Conscription in the Armed Forces, eds., Lars Mjoset and Stephen van Holde, 237254. Comparative Social Research 20. Emerald Group, 2002

\section{Websites}

Child Soldiers Global Report. Accessed December 1, 2014. http://www.childsoldiersglobalreport.org/. 
24 Music and Politics Winter 2015

War Child International Network on Child Soldiers. Accessed December 1, 2014.

http://www.warchild.org/links_resources/childsoldiers/childsoldiers.html.

\section{Radio Broadcasts}

Glasspiegel, Wills, and Drew Alt. "Proving the Bubu Myth: Janka Nabay, War and Witchcraft in Sierra Leone." Afropop Worldwide, July 17, 2014. https://soundcloud.com/afropop-worldwide/proving-thebubu-myth.

"Janka Nabay and the Bubu Gang on World Café." World Café, NPR, October 17, 2012.

http://www.npr.org/2012/10/17/163086359/janka-nabay-and-the-bubu-gang-on-world-café.

\section{Films}

Blood Diamond, directed by Edward Zwick. Warner Bros., 2006.

Johnny Mad Dog, directed by Jean-Stéphane Sauvaire. TFM Distribution, 2008. 


\begin{abstract}
This article will explore the role of music in the Sierra Leonean conflict and the extent to which music facilitated the construction of identities and the formation of social cohesion within the Revolutionary United Front (henceforth RUF) rebel movement. Moreover, it will look at the RUF's use of music as an instrument of terror in this war. First, I will briefly outline the dynamics that gave rise to the war, and then I will look into reasons for the widespread juvenile participation, touching on diverse motives and the heterogeneous composition of members within the RUF revolution. With regard to the juvenile combatants in this conflict, I will focus on how they utilized music in different ways, for different reasons and various ends.
\end{abstract}

